\title{
The Determinants for Accepting and Using e-Government Revenue Application (e-filing)
}

\author{
Mogaramedi Frans Mashabela \\ Unisa Graduate School of Business Leadership (SBL), \\ Corner Janadel and Alexandra Avenues, Midrand, 1685 \\ Gauteng Province, South Africa
}

\begin{abstract}
The determinants for accepting and using the e-Government revenue applications (e-filing) is a phenomenon most governments, including South Africa are still grappling with, and therefore, an ongoing information systems business leadership research is a key issue. The research problem is that despite the eGovernment revenue application being implemented and maintained at a high cost, there is little uptake and optimal use. The e-Government revenue application has greater benefits such as tax calculation accuracy, tax submission done timeously during any time of the day, improving tax efficiency by reducing administration cost. Since the value and the investment is huge, the burning question is then why the accepting and usage of e-Government revenue application by taxpayers not as it should? Information from previous studies are quite on this phenomenon, in the South African context and this then left a knowledge gaps, which this paper bridges. This paper focuses on explaining and exploring the determinants for adopting and using e-Government revenue application as reasons why some of taxpayers accept and use the revenue application while others are not using it are still unknown. Argument is that despite South Africa implemented a cutting-edge system since 2006, taxpayers still queue at its branches for manual submissions. There is a need to understand the determinants for acceptance and usage of eGovernment revenue application.
\end{abstract}

Keywords:- E-Government, revenue application, Tax knowledge, Tax Compliance, Technology acceptance and usage models i.e. Unified Theory of Acceptance and Use of Technology and Tax Compliance Models

\section{INTRODUCTION}

This paper explores the determinants for adopting and using the e-Government revenue application for submission of tax returns. Everyone who is earning an income is required by law to submit tax returns annually. Taxpayers may either file their tax returns via online through the eGovernment revenue application (e-filing) or they can physically go to a tax branch office to manually file tax returns.

According to Ishola (2016), tax is a compulsory levy collected by the tax authority from individual taxpayers and organisations in line with the tax laws of a country. Ibid, 2016, pointed that a fair system taxation is recommended

\author{
Professor Ray M Kekwaletswe \\ Unisa Graduate School of Business Leadership (SBL), \\ Corner Janadel and Alexandra Avenues, Midrand, 1685 \\ Gauteng Province, South Africa
}

and it need to be convenient and efficient. Taxes are payable on any type of earnings (Ibid, 2016). Biggest fear of users of information system globally is commonly the concern of sharing personal and confidential information when using any technology via online platforms. Laudon and Laudon (2013), mentioned that there is lots of vulnerabilities to many kinds of threats when huge personal data is kept in an electronic form than when in physical manual paper form.

Chances of unauthorised access to data which is stored electronically is evitable because data misuse can take place at any point where the system can be accessed. It is very critical that the tax authority's website for eGovernment revenue application must be highly secured as it is used by many taxpayers whose personal data might be at stake. Advice by Crews (2013), is that users of information system must avoid the usage of free public Wi$\mathrm{Fi}$ as it lacks security from data manipulations by third parties when accessing the system.

For example, the introduction of the Covid-19 pandemic globally, have increased the need for the usage of online platforms for services like the e-Government revenue application, offering of educational class sessions for schools, including tertiary institutions, etc. The implementation of e-Government revenue application in South Africa had moved it upwards on the world rankings on tax processing from position 32 to position 11 (Berger, 2011). It takes 200hours for a company in South Africa to process a tax return while the global average is 268 hours (Berger, 2011).

United States of America was the first to use a system of filing returns through electronically in 1986 (Lai and Choong, 2010). Users are motivated to submit their returns electronically on time and accurately when they are treated fairly (Kirchler, Niemirowski and Wearing, 2006).Taxpayers cooperate willingly when they are fairly treated, rules justifiable, decisions clarified, correct information provided when questions are asked and problems resolved (Kirchler, Niemirowski \& Wearing, 2006). A reliably integrated system in economically disadvantage countries is still to be implemented even though e-Government revenue application is accepted globally by citizens (Azmi and Kamarulzaman, 2010). Globally, e-services do not satisfy users of those systems because of scepticism, absence of digital skills, no system trust, complicated outcomes due to inadequate guidelines, etc. (Lee, Kim and Ahn, 2011). Taxpayers without 
computer skills might have challenges in submitting their returns electronically (Lee, Kim \& Ahn, 2011).

Easiness of using technology is crucial to the one who use such applications, thus user-friendly systems (Wirtz and Piehler 2016). Mustapha (2015), mentioned that successful implementation of e-tax depends on easy to use as a vital determinant while Gilbert, Balestrini \& Littleboy (2004), identified taxpayers not preferring e-Government revenue application than the traditional filing of returns if the application is enjoyable and ease to use. User acceptance to use an information system for the functionality supported by the design show their willingness (Dillon and Morris, 1996). Tax system that is not simple to use is a barrier for convenience, clarity and collection economies, system updates must be done continuously to be simplified (Marcus, 2007).

\section{$>$ e-Government}

Gupta, Dasgupta \& Gupta (2008) defines eGovernment as the application of information system. According to United Nations [UN] (2005), e-Government is explained as a usage and application of information system for service delivery to citizens. Leitner, 2003; Beynon \& Davies (2005), stated that electronic services are the tools provided by a government to make its democracy, transparency, and accountability better including its performance. Carter \& Belanger (2005), mentioned that eGovernment promotes simplicity of access for essential government services by its citizens.

Pardo et al. (2016), stated the vision of e-Governance being to establish improved public services offered for by governments to attain its objectives efficiently and effectively. According to United Nations (2016b), electronic government provide provides adequate services to people as an important tool encourage citizens to participate in raising issues pertaining to services provided.. Government administrations globally invest large sum of money annually in e-Government projects (World Bank 2016). Accepting and using the e-Government by citizens (G2C) remains low globally across the world (Shalhoub 2006; World Bank 2016).

Main reasons for lower adoption rate of eGovernment have were observed to be security, trust, risks involved and individual privacy (Shalhoub 2006; Zafiropoulos, Karavalisis and Vrana 2012). South African government implemented e-Government revenue applications also known as e-filing in 2006 via its tax authority being the South African Revenue Services (SARS), to enable electronic tax form submission for all taxpayers to utilise when doing tax returns (SANews, 2013).

\section{$>$ Accepting and using information system}

Fu, Farn \& Chao (2006) describes information system adoption by users being psychological state of mind regarding user's voluntary intention to use ICT. Perceived easy to use is the willingness a person have for believe the use of certain application will not require human effort to action the task to be done (Davis, 1991). Effortlessness in using a technology to perform a task is a user's subjective perception. Factors for perceived ease of use are: easiness, readable, simple language, comparable information and effortless when moving to the first page (Davis, 1991). Perceived easiness of using information system affect person's perception for learning and usage of technology (Venkatesh, 2000).

\section{$>$ Electronic filing as an e-Government tool for services}

Electronic filing is an application suitable for submission of returns to tax authority via the internet platforms (Barodiva and Bhargava, 2015). Electronic filing of tax return is a tool used by government deliver services to the community via an online platform $(\mathrm{Fu}, \mathrm{Farn}$, and Chao, 2006). The e-Government revenue application improves efficiency tax payments and quick refunds processing (Santhanamery and Ramayah, 2015). Accurate calculation of tax is the important benefit of the eGovernment revenue application because proof of submission is acknowledged immediately by the tax authority (Ibid., 2015). Tax administrative costs and workload decreases due to e-Government revenue application usage (Azmi \& Kamarulzaman, 2010; Santhanamery \& Ramayah, 2015). Electronic filing user must have basic computing skills and knowledge of information system for internet browsing.

e-Government revenue application use internet platforms where physical paper return is not required (Wasao, 2014). E-tax automates tax processes for submitting tax return with a aim of advancing efficiency (Fu et.al., 2006; Dowe, 2008; Fenwick and Browstone, 2002).

\section{$>$ Benefits of e-Government revenue application}

Auto-calculation of tax in computing minimises human errors and improves efficiency for processing (Santhanamery and Ramayah (2015). Authorities do not manually capture the tax returns which minimises mistakes during tax return processing (Santhanamery and Ramayah (2015). Tax return processing costs, safekeeping and handling are minimised (Azmi and Kamarulzaman, 2010). Taxpayers submit their returns at any time, which is convenient, and they system give notification immediately confirming transaction done. (Kumar and Anees, 2014).

\section{$>$ Concerns about the e-Government revenue application}

Ideally, fair tax system is necessary and should be simplified, enforceable and support economic prosperity for the community it serves (Slemrod and Bakija, 1996). It is inevitable for taxpayers' personal information to be subjected to security risks as e-filing uses internet platform (Hoffman, Novak and Peralta, 1999). For a taxpayer to file tax return successfully, they need to have basic computing skills as well as the knowledge of information technology to be able to browse the internet (Wirtz and Piehler, 2016). 
Taxpayers are afraid of using the revenue application due to threats to their private information, forgery and identity theft (De Castro, Cordero, De Chavez, Gabia, Mortel, Yortas, Manongsong \& Pateña, 2015). Taxpayers adopting and using e-Government revenue application are affected by the security threat fear for their personal information and that prevent them from using it ( $\mathrm{Lu}, \mathrm{Hsu}$ and Hsu, 2005). Perceived lack of security lowers the confidence of taxpayers from adopting and using the revenue application (Moorthy, Samsuri, Hussin, Othman \& Chelliah, 2014; Santhanamery \& Ramayah, 2015).

Factors influencing citizens when using eGovernment revenue application are trust and transaction security (Rehman, Esichaikul and Kamal, 2012). Taxpayers' attitudes are influenced by their compliance behaviours as it represents their opportunity for positive or negative action (Ajzen, 1993). Taxpayers' perceived risks influence their intension to use the electronic filing (De Castro, Cordero, De Chavez, Gabia and Mortel, 2015). Information system developers must thoroughly address system design, good online service and privacy assurance to encourage users to continue using e-services (Chen, Jubildo, Capistrano \& Yen, 2015).

\section{$>$ e-Government revenue application challenges}

Taxpayers incur tax compliance cost like internet usage or the use of a tax consultant who submits returns on his/her behalf even though tax return submission is free (Lu, Hsu and Hsu, 2005). Citizens need to have basic computing and internet skills to file returns via electronic filing (Ibid, 2010). As electronic operate on internet platforms, users incur data cost for accessing the revenue application via the internet and if they don't have data the only option will be to file their tax returns manually (Gilbert et al., 2004). When tax season approaches deadline taxpayers may experience system slow response due to network traffic as many people access the e-Government revenue application at the same time (Azmi and Kamarulzaman, 2010).

Acceptance and usage of the online tax is influenced by computer literacy level and internet infrastructure accessibility (Auyat, 2013). The adoption and usage of an e-tax is influence by taxpayer's confidence with online filing and lack of computer literacy that affect them psychologically (Muhangi, 2012). Taxpayers might be afraid of using the e-Government revenue application on because of lacking computer experience that increases anxiety and stress when using technology (Muhangi, 2012). Taxpayers might have a perception that the system is unreliable if it cannot properly carry large information during busy period and that will decrease their intensions of adopting and using it (Nakiwala, 2010).

One of the challenges with regard to revenue application is that user needs to remember password every time when accessing the system (Azmi and Kamarulzaman, 2010). Introduction of e-Governance is a challenge for many governments globally as difficulties might occurs in the initial stage and during system upgrade of the e-
Government sites (Kroukamp, 2005). Security of personal information collected and stored by government might be compromised if its security is breached on their websites (Ibid., 2005).

Lack of facilities and internet access lower the level of access to the electronic services the poor communities (OECD, 2003). Illiterate taxpayers are likely not to use technology services due to lack of computer skills and general education standard (Kroukamp, 2005). Taxpayers who are physically challenged should find it simpler navigate through e-Government websites, so governments must ensure accessibility of their e-services to all citizens (Ibid., 2005). Government as the service provider must embark on awareness campaign to educate people about the advantages e-Governance to improve citizens' confidence and persuade them to use the system (Ibid., 2005).

\begin{tabular}{|c|c|}
\hline Source & Definition \\
\hline $\begin{array}{l}\text { Gupta, Dasgupta and Gupta, } \\
2008\end{array}$ & $\begin{array}{l}\text { Electronic government is a known } \\
\text { technology used for providing services. }\end{array}$ \\
\hline United Nations, 2005 & $\begin{array}{l}\text { E-Government is the application of } \\
\text { information system to provide services to } \\
\text { the citizens. }\end{array}$ \\
\hline $\begin{array}{l}\text { Leitner, 2003; Beynon and } \\
\text { Davies } 2005\end{array}$ & $\begin{array}{l}\text { E-Government services are tools for } \\
\text { improving democracy, transparency, and } \\
\text { accountability. }\end{array}$ \\
\hline Carter and Belanger, 2005 & $\begin{array}{l}\text { Electronic services promotes acces and } \\
\text { simplify the provision of essential services } \\
\text { to people. }\end{array}$ \\
\hline Fu, Farn, and Chao, 2006 & $\begin{array}{l}\text { Technology adoption refers to a person's } \\
\text { psychological state for voluntarily deciding } \\
\text { to use information system. }\end{array}$ \\
\hline Barodiva and Bhargava, 2015 & $\begin{array}{l}\text { Electronic filing is an application for filing } \\
\text { returns va the internet. }\end{array}$ \\
\hline Wasao, 2014 & $\begin{array}{l}\text { Electronic filing is a process f submitting } \\
\text { returns electronically with no need to } \\
\text { submit physical tax return form. }\end{array}$ \\
\hline Fu, Farn and Chao, 2006 & $\begin{array}{l}\text { Electronic filing is a tool service delivery } \\
\text { via an online platform. }\end{array}$ \\
\hline
\end{tabular}

Table 1:- Authors' describing e-Government, technology adoption and revenue application

\section{SURVEY OF SCHOLARSHIP}

Theoretical models that were developed in previous studies for exploring and explaining the determinants for technology acceptance and usage being the Unified Theory of Acceptance and Use of Technology (UTAUT) and Tax Compliance models. Existing literature have no known model developed which outline the determinants to consider for adopting and using e-Government revenue application as well as reasons why some taxpayers adopt and use it in the context of South African conditions. This study develops a model that can be practically applied as a solution to the challenges of accepting and using the eGovernment revenue application by integrating these previous theories. An e-Government revenue application (e-filing) is administered by the South African tax authority where individuals and organisations earning an income need to use when submitting their tax returns. 
This study focuses on individual taxpayers and gives insights into what really drives them to adopt and use the revenue application as well as factors inhibiting its adoption and usage. This study contributes theoretically, methodologically, practically and contextually by doing exploration through the UTAUT and Tax Compliance theories as lenses for exploring and explaining the determinants influencing the acceptance and usage of the eGovernment revenue application. A questionnaire was used to collect data for analysis where opinions and views of satisfactorily sample size of taxpayers using e-Government revenue application as well as those who are not using it were captured. Developed model in this study explores the level to which each determinant significantly predict and explain the acceptance and usage of e-Government revenue application in the context of South Africa. The tax authority may practically use the developed model to ensure that most taxpayers optimally use the e-Government revenue application.

Table 2 below depicts authors explaining factors predicting technology acceptance and usage

Table 2 below depicts elements which were assessed in different settings and found being significant factors influencing technology adoption and usage. This study tested these elements to assess their relevancy to the conditions of South Africa.

\begin{tabular}{|c|c|c|c|}
\hline $\begin{array}{l}\text { Factors } \\
\text { predicting } \\
\text { technology } \\
\text { acceptance and } \\
\text { us age }\end{array}$ & Title/Description & $\begin{array}{l}\text { From which } \\
\text { Model }\end{array}$ & Author/s \\
\hline $\begin{array}{l}\text { Perceived ease of } \\
\text { use }\end{array}$ & $\begin{array}{l}\text { Perceived us efulness, perceived } \\
\text { ease of use and user } \\
\text { acceptance of information } \\
\text { technology. MIS Quarterly, } \\
\text { 13(3), pp. 319-340. }\end{array}$ & PEOU & Davis, F.D. (1989). \\
\hline $\begin{array}{l}\text { Perceived } \\
\text { us efulness }\end{array}$ & $\begin{array}{l}\text { Perceived usefulness, perceived } \\
\text { ease of use and user } \\
\text { acceptance of information } \\
\text { technology. MIS Quarterly, } \\
\text { 13(3), pp. 319-340. }\end{array}$ & PU & Davis, F.D. (1989). \\
\hline $\begin{array}{l}\text { Performance } \\
\text { Expectancy }\end{array}$ & $\begin{array}{l}\text { User Acceptance of Information } \\
\text { Technology: Toward a Unified } \\
\text { View. MIS Quarterly, 27, 425- } \\
\text { 478. }\end{array}$ & UTAUT & $\begin{array}{l}\text { Venkatesh, V., } \\
\text { Morris, M. G and } \\
\text { Davis, G. B (2003). }\end{array}$ \\
\hline $\begin{array}{l}\text { Effort } \\
\text { Expectancy }\end{array}$ & $\begin{array}{l}\text { User Acceptance of Information } \\
\text { Technology: Toward a Unified } \\
\text { View. MIS Quarterly, 27, 425- } \\
478\end{array}$ & UTAUT & $\begin{array}{l}\text { Venkatesh, V., } \\
\text { Morris, M. G and } \\
\text { Davis, G. B (2003). }\end{array}$ \\
\hline Social Influence & $\begin{array}{l}\text { Information technology } \\
\text { acceptance by individual } \\
\text { professionals: a model } \\
\text { comparison approach. Decision } \\
\text { Sciences, } 32 \text {. }\end{array}$ & $\begin{array}{l}\text { A Model } \\
\text { Comparis on } \\
\text { Approach }\end{array}$ & $\begin{array}{l}\text { Chau, Y. K and Hu, } \\
\text { J. H (2001). }\end{array}$ \\
\hline $\begin{array}{l}\text { Performance } \\
\text { Impact }\end{array}$ & $\begin{array}{l}\text { Task-technology fit and } \\
\text { individual performance } M I S \\
\text { Quarterly; Jun 1995; 19, 2; } \\
\text { ABI/INFORM Global pg. 213- } \\
236 .\end{array}$ & TTF & $\begin{array}{l}\text { Goodhue, D.L and } \\
\text { Thompson, R. L } \\
\text { (1995) }\end{array}$ \\
\hline Tax Behaviour & $\begin{array}{l}\text { Detection Probability and } \\
\text { Taxpayer Compliance: A } \\
\text { Review of the Literature. J. Acc. } \\
\text { Lit. 11: } 1-46 .\end{array}$ & $\begin{array}{l}\text { Tax } \\
\text { Compliance } \\
\text { Model }\end{array}$ & $\begin{array}{l}\text { Fischer CM, } \\
\text { Wartick M, Mark M } \\
\text { (1992). }\end{array}$ \\
\hline \multirow{3}{*}{$\begin{array}{l}\text { Behavioural } \\
\text { Intention }\end{array}$} & $\begin{array}{l}\text { The theory of planned } \\
\text { behaviour. Organisational } \\
\text { behaviour and human decision } \\
\text { processes, } 50(1) \text {, pp. } 179-211 .\end{array}$ & TPB & Ajzen, I. (1991). \\
\hline & $\begin{array}{l}\text { Belief, Attitude, Intention and } \\
\text { Behaviour: AN Introduction to } \\
\text { theory and Research. Reading, } \\
\text { MA: Addison-Wesley. }\end{array}$ & & \\
\hline & & TRA & $\begin{array}{l}\text { Fishbein, } M \text { and } \\
\text { Ajzen, I (1975). }\end{array}$ \\
\hline $\begin{array}{l}\text { Information } \\
\text { quality }\end{array}$ & $\begin{array}{l}\text { The DeLone and McLean model } \\
\text { of information systems success: } \\
\text { A ten-year update. Journal of } \\
\text { Management Information } \\
\text { Systems, 19(4), 9-30. }\end{array}$ & $\begin{array}{l}\text { IS Success } \\
\text { Model }\end{array}$ & $\begin{array}{l}\text { DeLone, W. H., \& } \\
\text { McLean, E. R. } \\
\text { (2003). }\end{array}$ \\
\hline Education & $\begin{array}{l}\text { "User acceptance of } \\
\text { information technology: toward } \\
\text { a unified view", MIS Quarterly, } \\
\text { Vol. } 27 \text { No. 3, pp. 425-478. }\end{array}$ & UTAUT & $\begin{array}{l}\text { Venkatesh, V., } \\
\text { Morris, M., Davis, } \\
\text { G. and Davis, F. } \\
\text { (2003), }\end{array}$ \\
\hline
\end{tabular}

Table 2:- Authors on factors predicting technology acceptance and usage 
Table 3 below depicts authors explaining factors that are technology enablers and disablers for acceptance and usage.

Table 3 below depicts constructs which have been discovered to significantly enables and disables technology adoption and usage after being tested in various settings globally. The determinants list for that inhibit or enables the adoption and usage of technology is endless, so frequently assessed elements were chosen.

\begin{tabular}{|c|c|c|c|}
\hline $\begin{array}{c}\text { Technology } \\
\text { Enablers and } \\
\text { Disablers }\end{array}$ & Description & From which Model & Author \\
\hline $\begin{array}{l}\text { Facilitating } \\
\text { Conditions }\end{array}$ & $\begin{array}{l}\text { "Us er acceptance of information } \\
\text { technology: toward a unified } \\
\text { view", MIS Quarterly, Vol. } 27 \text { No. } \\
\text { 3, pp. 425-478. }\end{array}$ & UTAUT & $\begin{array}{l}\text { Venkatesh, V., } \\
\text { Morris, M., Davis, G. } \\
\text { and Davis, F. (2003), }\end{array}$ \\
\hline Compatibility & $\begin{array}{l}\text { Acceptance of electronic tax filing: } \\
\text { a study of taxpayer intentions. } \\
\text { Information \& Management, } 43 \text {, } \\
\text { pp. 109-126. }\end{array}$ & $\begin{array}{l}\text { A Study of Taxpayer } \\
\text { Intensions }\end{array}$ & $\begin{array}{l}\text { Fu, J.R., Farn, C.K. } \\
\text { and Chao W.P. } \\
\text { (2006). }\end{array}$ \\
\hline \multirow[b]{2}{*}{ Trust } & $\begin{array}{l}\text { The role of security and trust in the } \\
\text { adoption of online tax filing. } \\
\text { Transforming Government: People, } \\
\text { Process, Policy, 5(4), pp. 303-318. }\end{array}$ & $\begin{array}{l}\text { Transforming } \\
\text { Government, People, } \\
\text { Processes and Policy }\end{array}$ & $\begin{array}{l}\text { Carter, L., Schaupp, } \\
\text { L.C., Hobbs, J. and } \\
\text { Campbell, R. (2011a). }\end{array}$ \\
\hline & $\begin{array}{l}\text { The U.S. e-file initiative: an } \\
\text { investigation of the antecedents to } \\
\text { adoption from the individual } \\
\text { taxpayers' perspective. E - Service } \\
\text { Journal, } 7(3), \text { pp. } 219 .\end{array}$ & $\begin{array}{l}\text { An investigation of } \\
\text { the antecedents to } \\
\text { adoption from the } \\
\text { individual taxpayers' } \\
\text { perspective. }\end{array}$ & $\begin{array}{l}\text { Carter, L., Schaupp, } \\
\text { L.C. and McBride, } \\
\text { M.E. }(2011 b) \text {. }\end{array}$ \\
\hline $\begin{array}{l}\text { Computer Self- } \\
\text { efficacy }\end{array}$ & $\begin{array}{l}\text { The adoption of electronic tax } \\
\text { filing systems: an empirical study. } \\
\text { Government Information Quarterly, } \\
\text { 20(1), pp. 333-352. }\end{array}$ & An Empirical Study & Wang, Y.S. (2002). \\
\hline \multirow[b]{2}{*}{$\begin{array}{l}\text { Tax General } \\
\text { Knowledge }\end{array}$} & $\begin{array}{l}\text { The Association of Chartered } \\
\text { Certified Accountants, ACCA, } \\
\text { London. www.accaglobal.com. }\end{array}$ & $\begin{array}{l}\text { The Management of } \\
\text { Tax Knowledge. }\end{array}$ & $\begin{array}{l}\text { Hass eldine, J., } \\
\text { Holland, K. and Rijt, } \\
\text { P.V. (2009) }\end{array}$ \\
\hline & $\begin{array}{l}\text { Problems and solutions. } \\
\text { ACCAMADIA, Journal of Faculty } \\
\text { of Accountancy, Faculty of } \\
\text { Accountancy, UiTM Shah Alam } \\
\text { 11(2): 6-35. }\end{array}$ & $\begin{array}{l}\text { Taxilliteracy in } \\
\text { Malaysia }\end{array}$ & Barjoyai, B (1992). \\
\hline \multirow[b]{2}{*}{ Perceived Risk } & $\begin{array}{l}\text { A Perceived Risk Facets } \\
\text { Perspective. Int. J. Hum. Comput. } \\
\text { Stud. 59(1): 451-474. }\end{array}$ & $\begin{array}{l}\text { Predicting e-Services } \\
\text { Adoption }\end{array}$ & $\begin{array}{l}\text { Featherman M.S and } \\
\text { Pavlou P.A (2003). }\end{array}$ \\
\hline & $\begin{array}{l}\text { The role of trust, perceived risk, } \\
\text { and their antecedents," Decision } \\
\text { Support Systems (442), 2008, pp. } \\
\text { 544-564. }\end{array}$ & $\begin{array}{l}\text { "A trust-based } \\
\text { consumer decision- } \\
\text { making model in } \\
\text { electronic commerce }\end{array}$ & $\begin{array}{l}\text { Kim, D. J., D. L. } \\
\text { Ferrin, and Rao, R } \\
\text { (2008). }\end{array}$ \\
\hline
\end{tabular}

Table 3:- Authors for technology enablers and disablers

\section{THEORITICAL FRAMEWORK}

The Unified Theory of Acceptance and Use of Technology was created to be a solution to the challenges and contradictions created by the eight theories that where integrating to develop the UTAUT model (Venkatesh, Morris and Davis, 2003). The aim of this theory is to understand behavioural intention of using technology and the subsequent actual usage attitude as the dependent variable. The UTAUT theory consist of these elements: performance expectancy, effort expectancy, social influence, and facilitating conditions.
- The Unified Theory of Acceptance and Use of Technology

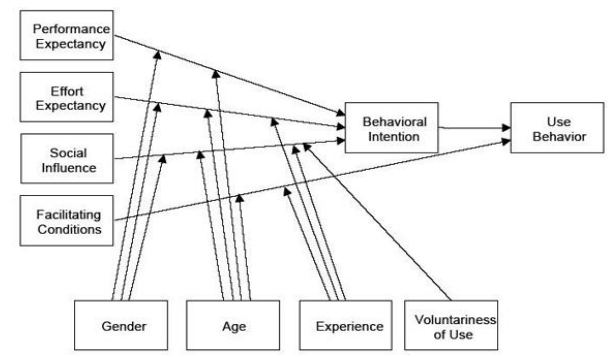

Fig 1:- Flow diagram of UTAUT process

Source: Venkatesh, Morris, Davis and Davis, 2003 
The Tax Compliance Model (TCM) emphasize that variables for demographics influence compliance of taxpayer by their effect on tax evasion attitudes, perceptions and opportunities. The TCM model have the following elements: tax compliance behaviour, demographic (e.g.- age, gender and education), tax evasion options (e.g. level of income, source of income and position), attitudes and perceptions (e.g. tax system fairness and peer influence) and tax system (e.g. complexity of the tax system, detection chances, penalties and tax rates)

\section{- $\quad$ Tax Compliance Model (TCM)}

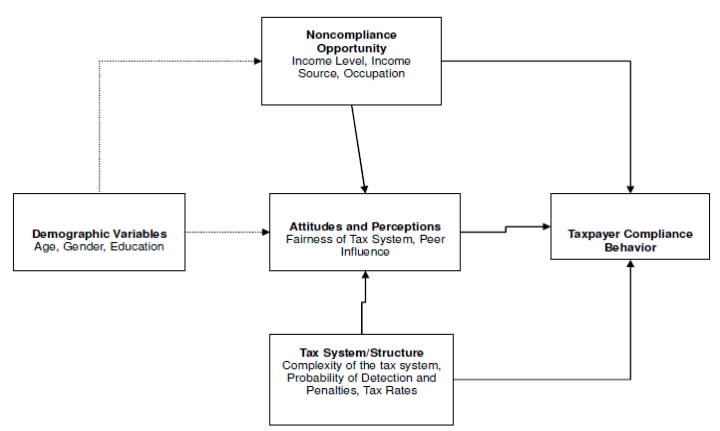

Fig 2:- Flow diagram of the Tax Compliance Model

Source: Fischer, Wartick and Mark, 1992.

Technology adoption and usage theories being UTAUT and Tax Compliance were applied independently in various settings, however, in these studies these models have been integrated to address the research problem. These prior theories were used independently from each other in previous studies. Integration of these theories assisted in developing solutions to address the identified problem and gaps being unique to the conditions in South Africa.

\section{CONCEPTUAL RESEARCH MODEL}

The developed conceptual model for acceptance and usage of the revenue application in this study gives a solid foundation for analysis work done to which is based on tested hypothesis suitable for exploration. The conceptual model was constructed with the combination of elements from UTAUT and Tax Compliance models. Conceptual structure statements offer basic theory of what the study is about together with reasons why this phenomenon take place (Bickman and Rog, 2008). Conceptual model is a graphic business model giving details about the key factors, ideas or variables that needs exploration regarding the relationships between them (Miles et al., 1994).

Explored hypotheses regarding the conceptual research model has elements sourced out of UTAUT and Tax Compliance models. Theory can't be proven by multiple outcomes because if one instance refuting that findings it means then that the theory demonstrate it as false (Popper, 1968). Theory is established by comparing observable data and hypotheses with more than two constructs explain the relationships (Popper, 1968) The UTAUT and TCM theories cannot be used in isolation to address the challenges of technology adoption and usage in South Africa context as they might be irrelevant, hence they were integrated in this study.

\section{Hypotheses}

Behavioural intention (BI) for accepting revenue application is the dependent variable.

Hypotheses per each element:

H1: Effort Expectancy affecting behavioural intention to use the revenue application.

H2: Social Influence affecting behavioural intention to use the revenue application.

H3: Facilitating conditions affecting intention to use the revenue application.

H4: Behavioural Intention affecting the revenue application usage.

H5: Tax Compliance behaviour affecting behavioural intention to use the revenue application.

H6: Tax Compliance behaviour affecting revenue application acceptance and usage.

The Conceptual Research Model for Acceptance and Usage of e-Government Revenue Application

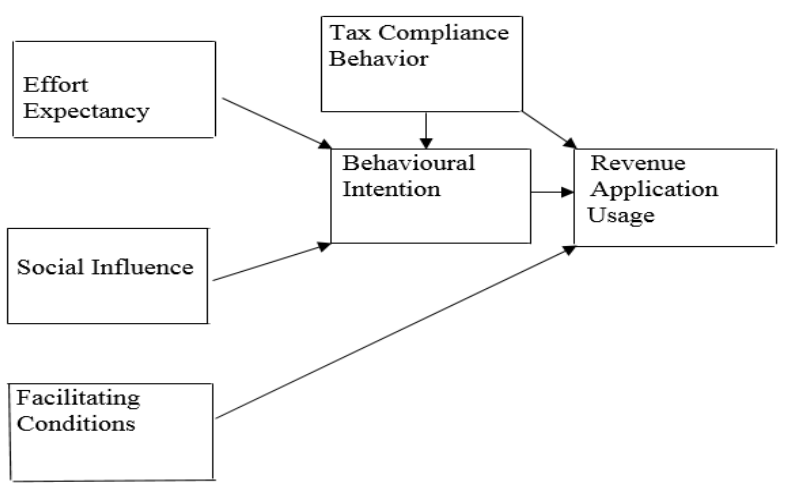

Fig 3:- The flow diagram of The Conceptual Model for adoption and usage of revenue application

\section{METHODOLOGY}

This study is based on critical reality with regard to epistemological position, it indicates that existence of reality exist beyond what is seen or observed. This study took subjectivism stance with regard to ontological position, it indicated that social phenomena occur based on the ideas and subsequent actions of social participants (Easterby-Smith, Thorpe and Lowe, 2006). Reality beyond what is observed in relation to the adoption and usage of the e-filing is required for understanding what drive taxpayers' to use or not use e-filing. This paper took a positivistic stance that implies that research outcomes are presented as objective facts and verified truths (Crotty, 1998). Research strategy in this study is a positivist using a quantitative method for data collection. Sampling technique adopted in this study was a simple random and sample frame was South African taxpayers submitting returns annually. A questionnaire was administered for collection of primary data that was analyzed using the structural 
equation modelling (SEM), confirmatory factor analysis (CFA), path modelling and Smart PLS software.

\begin{tabular}{l|l|l|}
\multicolumn{1}{c|}{$\begin{array}{c}\text { Research } \\
\text { Process }\end{array}$} & \multicolumn{1}{c|}{ Methods } & \multicolumn{1}{c|}{ Reason } \\
\hline $\begin{array}{l}\text { Research } \\
\text { Philosophy }\end{array}$ & Positivist & $\begin{array}{l}\text { Objective facts and } \\
\text { established truth }\end{array}$ \\
\hline $\begin{array}{l}\text { Research } \\
\text { Strategy }\end{array}$ & Quantitative & To reach many participants \\
\hline Data Collection & $\begin{array}{l}\text { Survey } \\
\text { (Questionnaire) }\end{array}$ & Easy to administer \\
\hline Sample Frame & $\begin{array}{l}\text { Taxpayers } \\
\text { (manual \& e-filers) }\end{array}$ & $\begin{array}{l}\text { Only individuals submitting } \\
\text { tax returns }\end{array}$ \\
\hline $\begin{array}{l}\text { Sample } \\
\text { Technique }\end{array}$ & $\begin{array}{l}\text { Simple Random } \\
\text { Sampling }\end{array}$ & $\begin{array}{l}\text { All participants have a } \\
\text { chance of being selected }\end{array}$ \\
\hline Unit Analysis & Individuals & $\begin{array}{l}\text { Individuals available } \\
\text { everywhere in the country }\end{array}$ \\
\hline Data Analysis & $\begin{array}{l}\text { Structural } \\
\text { Equation } \\
\text { Modelling }\end{array}$ & $\begin{array}{l}\text { Statistical technique for } \\
\text { studying relationships } \\
\text { between latent variables (or } \\
\text { constructs) }\end{array}$ \\
\hline
\end{tabular}

Table 4:- depicts the summary of Methodology

\section{DISCUSSIONS OF RESULTS}

\section{A. Structural Equation Modelling Approach}

Structural Equation Modeling (SEM) was applied for this paper for data analysis. SEM is a technique used for assessing relationships between elements(SchermellehEngel, Klein \& Moosbrugger, 2017). Prior authors believed in creating theoretical concepts and use two or more structural equations to validate proposed causal relationships (Bollen, 1989; Brewer et al., 2015; Byrne, 2016; Hair et al, 2016; Henseler et al., 2015 and Hair et al., 2017). SEM performing same functions as regression analysis with an additional benefit being the ability to measure relationship on elements and account for measurement error at the same time (Hox, et al., 2017). SEM is a well know technique used for data analysis being able to address numerous modelling challenges relating to the indigeneity among elements (Preacher, Zhang \& Zyphur, 2016).

\section{B. Structural Equation Modelling, A Component based Approach}

Statistical analyses where done on the Measurement and structural models using the Smart PLS software. Discussions below are relating to the variables descriptive statistics and reliability of the model. The Structural Equation Modelling, Confirmatory Factor Analysis and Path Modelling assessed in this study are discussed below. Model Fit was assessed by applying Confirmatory Factor Analysis (CFA) as well as reliability and validity of the scales used in the questionnaire. Scales validity was established by comparing the shared variance together with the average variance extracted (AVE). Path Modelling (PM) was achieve by testing Model fit and hypothesis. Significant statistical relationships between the elements was assessed using the bootstrap resampling method. Evidence on the reliability and validity of the assessment model is presented below in table 5 .

\section{Measurement Model Assessment}

\section{$>$ Summary of Measurement Model Assessment} (Confirmatory Factor Analysis)

Conceptual model has eight elements, which are Behavioural Intension, Effort Expectancy, E-filing Usage, Facilitating Conditions, Social Influence and Tax Compliance Behaviour. Results of testing elements for reliability and validity are shown in table 5 below.

\begin{tabular}{|c|c|c|c|c|c|c|c|c|}
\hline & \multirow[t]{2}{*}{$\begin{array}{l}\text { Researth } \\
\text { constructs }\end{array}$} & \multicolumn{2}{|c|}{ Scale Hems } & \multirow[t]{2}{*}{$\begin{array}{l}\text { Hem to-Total } \\
\text { Correla fon Value }\end{array}$} & \multirow[t]{2}{*}{$\begin{array}{l}\text { Cronbact's } \\
\text { Alpha Value }\end{array}$} & \multirow{2}{*}{$\begin{array}{l}\text { Composite } \\
\text { Reliability } \\
\text { Values }\end{array}$} & \multirow[t]{2}{*}{$\begin{array}{l}\text { Avera ge Varianoe } \\
\text { Extracted (AV/日) }\end{array}$} & \multirow[t]{2}{*}{ Factor } \\
\hline & & Mean & SD & & & & & \\
\hline \multirow{3}{*}{ в } & B1 & 2482 & 1.071 & 0.675 & \multirow{3}{*}{0.84} & \multirow{3}{*}{0908} & \multirow{3}{*}{0.786} & 0.45 \\
\hline & 82 & 2283 & 1.006 & $0 . \bar{B} 6$ & & & & 0.895 \\
\hline & B3 & 2228 & 1.068 & 0.717 & & & & 0.805 \\
\hline \multirow{6}{*}{$\mathbb{E}$} & $\llbracket 1$ & 2398 & 1.113 & 0.075 & \multirow{6}{*}{0.808} & \multirow{6}{*}{0914} & \multirow{6}{*}{0.069} & 0.808 \\
\hline & $\mathbb{E 2}$ & $245 T$ & 1.006 & 0.025 & & & & 0.79 \\
\hline & \pm 3 & 2854 & 1.02 & 0.718 & & & & 0.785 \\
\hline & $\mathbb{E 4}_{4}$ & 3042 & 1.12 & 0.72 & & & & 0.794 \\
\hline & $\llbracket 5$ & 294 & 1.1 & 0.724 & & & & 0.799 \\
\hline & E6 & 2883 & 1.128 & 0.788 & & & & 083 \\
\hline \multirow{3}{*}{ Ev } & E41 & 2188 & 1.007 & 0.108 & \multirow[b]{3}{*}{0.88} & \multirow[b]{3}{*}{0897} & \multirow[b]{3}{*}{0.745} & 0.817 \\
\hline & EV2 & $233 \pi$ & 1.060 & 0.784 & & & & 0.902 \\
\hline & E13 & 2438 & 1.198 & 08 & & & & 0.791 \\
\hline \multirow{9}{*}{$\mathrm{FC}$} & $\mathrm{FC1}$ & 2494 & 1.263 & 0.508 & \multirow{9}{*}{0.812} & \multirow{9}{*}{02888} & \multirow{9}{*}{057} & 0.732 \\
\hline & $\mathrm{FC2}$ & 2818 & 1.28 & 0.71 & & & & 0.827 \\
\hline & $\mathrm{FC3}$ & $3.18 \%$ & 1.128 & 0.005 & & & & 073 \\
\hline & $\mathrm{FC4}$ & $2 \pi \pi$ & 1.11 & 0.583 & & & & 0.78 \\
\hline & $\mathrm{FC5}$ & 2735 & 1,051 & 0.552 & & & & 0.722 \\
\hline & A2 & 2,400 & 1.198 & 0.789 & & & & 0.886 \\
\hline & A3 & 2863 & 1.187 & 0.713 & & & & 0.813 \\
\hline & P4 & 2082 & 1.119 & 0.778 & & & & 0.899 \\
\hline & R5 & 2518 & 1.128 & 0.789 & & & & 0.877 \\
\hline \multirow{5}{*}{$\mathbf{s}$} & $\$ 1$ & 2500 & 1.094 & $0 \infty 11$ & \multirow{5}{*}{$0.8 \%$} & \multirow{5}{*}{09033} & \multirow{5}{*}{0.063} & 0.818 \\
\hline & 92 & 2414 & 1.051 & 0.787 & & & & 0.885 \\
\hline & 93 & 2780 & 1.14 & 0.005 & & & & 078 \\
\hline & 94 & 2487 & 1.118 & 0.72 & & & & 0.862 \\
\hline & 95 & 274 & $1.1 \%$ & 0.531 & & & & 0.701 \\
\hline \multirow{6}{*}{ TCB } & TCET & 2804 & 1.138 & 0.739 & & & & 0.825 \\
\hline & TCEQ & 2686 & 1.135 & 0.006 & & & & 0.792 \\
\hline & TCEB & 2986 & 1.048 & $0 . \pi 8$ & & & & 0.794 \\
\hline & TCBA & $296 \%$ & 1.046 & 0.788 & & & & 0.845 \\
\hline & TCES & 2958 & 1.024 & 0.727 & $08 \pi$ & 0908 & 0.619 & 0.815 \\
\hline & TCBO & 2500 & 1.008 & 0.467 & & & & 0.831 \\
\hline
\end{tabular}

Table 5:- Scale Accuracy Analysis

Note: $B I=$ Behavioural Intension; $E E=$ Effort Expectancy; $E U=$ Efiling Usage $; F C=$ Facilitating Conditions $; S I=$ Social Influence; $T C B=$ Tax Compliance Behaviour; $S D=$ Standard Deviation; $C R=$ Composite Reliability $A V E=$ Average Variance Extracted

* Scores: 1 -Strongly Disagree; 3 -Moderately Agree; 5 Strongly Agree

\section{Reliability and Validity tests in Confirmatory Factor Analysis}

Guidance in determining reliability and validity were sourced from previous studies conducted by Devine \& Hughes, 2016; Canivez, 2016; Willoughby et al., 2017). Reliability indicates variance amount in an item as an element rather than to the error (Chau, 1997). Discriminant 
and convergent validity assessed using Average Variance Extracted (Crego et al., 2015).

\begin{tabular}{|c|c|c|c|}
\hline & $\begin{array}{l}\text { Cronbach's } \\
\text { Alpha }\end{array}$ & $\begin{array}{l}\text { Composite } \\
\text { Reliability }\end{array}$ & $\begin{array}{l}\text { Average } \\
\text { Variance } \\
\text { Extracted (AVE) }\end{array}$ \\
\hline$\overline{\mathrm{BI}}$ & 0.847 & 0.908 & 0.766 \\
\hline$\overline{\mathrm{EE}}$ & 0.888 & 0.914 & 0.639 \\
\hline$E U$ & 0.828 & 0.897 & 0.745 \\
\hline FC & 0.812 & 0.868 & 0.57 \\
\hline SI & 0.866 & 0.903 & 0.653 \\
\hline TCB & 0.875 & 0.906 & 0.619 \\
\hline
\end{tabular}

Table 6:- Measurement Instrument Assessment (Confirmatory Factor Analysis)

\section{$>$ Testing for Reliability}

- Cronbach's Alpha (CA)

Measurement scale was evaluated applying Cronbach's alpha coefficient composite reliability (CR) to verify the internal consistency in checking the reliability of the measurements. Cronbach's alpha coefficient over 0.6 is a recommended reliable values (Diedenhofen and Musch (2016). Instrument reliability was measured with Cronbach alpha and all values are above the accepted threshold of 0.6 , as indicated in Table 6 and indicating that all assessment instruments are reliable.

\section{- Composite Reliability $(C R)$}

Composite reliability index over 0.7 is recommended (Diedenhofen and Musch (2016). Facilitating Conditions has the smallest composite reliability $(\mathrm{CR})$ value of 0.868 and Effort Expectancy has the highest composite reliability value of 0.914 in this study. Composite reliability exceeded the threshold of greater than 0.7 for all values in this study as indicated in Table 6.

\section{- Average Variance Extracted}

Variance in indicators was determined by applying the average variance extracted indicated by the latent variable. An element with AVE value that is greater than 0.5 is considered reliable (Wilcox, 1996). All variables fall within the acceptable threshold of 0.5 according to AVE results in Table 6.

AVE is calculated manually with this formula:

$\mathrm{AVE}=\boldsymbol{\Sigma} \gamma \mathbf{y i 2} /[\boldsymbol{\Sigma} \gamma \mathbf{y i 2}+\mathbf{\Sigma} \boldsymbol{\varepsilon i}]$.

All scales were internally consistent and reliable as per extracted constructs reliabilities and the average variance according to results shown in table 6.

\section{- Convergent Validity}

The level that an element converges in its indicators by explaining the items' variance is measured by the convergent validity (Zelkowitz and Cole, 2016). Item-total correlation and factor loading measures verifies convergent validity (Crego et al., 2015; Hair et al., 2016). Factor loading estimates over 0.5 are shown in table 5 indicating convergent validity. The lowest representing Tax Compliance Behaviour (TCB6) show the lowest factor loading of 0.631 while E-filing Usage (EU2) have the highest factor loading of 0.922 .

\section{- Discriminant validity}

Correlation matrix is applied to measure the discriminant validity (Chinomona, (2011). Discriminant validity was confirmed as the value for correlation between variables is recommended to be below 1.0 and intercorrection values for all variables are below 1.0 as indicated in Table 7. All measurement in this study meets the recommended threshold as per results obtained and the highest being value is 0.761 . Average variance extracted value was compared to their Highest Shared Variance (HSV) to assess the discriminant validity which was confirmed (Hox, et al., 2017).

\begin{tabular}{|l|l|l|l|l|l|l|}
\hline & BI & EE & EU & FC & SI & TCB \\
\hline BI & 1 & & & & & \\
\hline EE & 0.445 & 1 & & & & \\
\hline EU & 0.761 & 0.509 & 1 & & & \\
\hline FC & 0.538 & 0.697 & 0.569 & 1 & 1 & \\
\hline SI & 0.439 & 0.555 & 0.551 & 0.607 & 0.581 & 1 \\
\hline TCB & 0.587 & 0.71 & 0.619 & 0.723 & & \\
\hline
\end{tabular}

Table 7:- Correlation Matrix

Discriminant validity is obtained through comparison of Average Variance Extracted (AVE) and Highest Shared Variance (HSV). Discriminant validity exist when AVE is greater than HSV. Table 8 indicates results that showing all AVEs being greater than the HSVs of the elements that confirm the discriminant validity.

\begin{tabular}{|c|c|c|c|}
\hline & $\begin{array}{c}\text { Average } \\
\text { Variance } \\
\text { Extracted } \\
\text { (AVE) }\end{array}$ & $\begin{array}{c}\text { Highest } \\
\text { Shared } \\
\text { Variance } \\
\text { (HSV) }\end{array}$ & \multicolumn{1}{|c|}{ Decision } \\
\hline BI & 0.766 & 0.579 & $\begin{array}{l}\text { Discriminant } \\
\text { Validity } \\
\text { confirmed }\end{array}$ \\
\hline EE & 0.639 & 0.504 & $\begin{array}{l}\text { Discriminant } \\
\text { Validity } \\
\text { confirmed }\end{array}$ \\
\hline EU & 0.745 & 0.579 & $\begin{array}{l}\text { Discriminant } \\
\text { Validity } \\
\text { confirmed }\end{array}$ \\
\hline FC & 0.57 & 0.522 & $\begin{array}{l}\text { Discriminant } \\
\text { Validity } \\
\text { confirmed }\end{array}$ \\
\hline SI & 0.653 & 0.368 & $\begin{array}{l}\text { Discriminant } \\
\text { Validity } \\
\text { confirmed }\end{array}$ \\
\hline TCB & 0.619 & $\begin{array}{l}\text { Discriminant } \\
\text { Validity } \\
\text { confirmed }\end{array}$ \\
\hline
\end{tabular}

Table 8:- Comparison between AVE and HSV Results

\section{Model Fit Summary-Measurement Model}

Three categories of Model fit analysis outcome are absolute fit indices, incremental fit indices and parsimony fit indices. The CMIN or the Chi-square $\left(\chi^{2} / \mathrm{df}\right)$, Normed Fit Index (NFI), Goodness-Of-Fit Index(GFI), Root Mean Square Error of Approximation (RMSEA), Tucker Lewis Index (TLI), Comparative Fit index (CFI) and Incremental 
ISSN No:-2456-2165

Fit Index (IFI) indices were extracted from the analysis result obtained. The Chi-square (CMIN/DF) threshold of 3 is acceptable, however, in table 9 it was found to be 2.124 (Chinomona (2011).

Acceptable threshold level of 0.900 is recommended for the CFI, however, in this study it was found to be 0.908 (Hooper, Coughlan and Mullen (2008). GFI acceptable threshold of at least 0.9 is recommended and GFI was found to be 0.914 (Baumgartner and Hombur, 1996). Relative fit index (RFI) value of 0.9 is recommended and in this study it was found to be 0.906 (McDonald and Ho, 2002). Normed fit index (NFI) threshold is acceptable at a value of 0.900 and it was found to be 0.903 (Bentler and Bonett, 1980).

The incremental fit index (IFI) 0.909 was realised and it exceeds the recommended value of 0.900 (Bollen, 1989). The Tucker-Lewis Index (TLI) acceptable threshold is 0.900 and in this study it was found to be 0.915 (Hooper et al., 2008). The root mean square error of approximation (RMSEA) thresholds is acceptable at 0.08 and it was found to be 0.069 in this study. Results shows all model fit indices being at recommended levels as indicated in the Table 9.

\begin{tabular}{|c|c|c|c|}
\hline Model Fit Indices & $\begin{array}{l}\text { Acceptable } \\
\text { Threshold }\end{array}$ & $\begin{array}{l}\text { Current } \\
\text { Study } \\
\text { Threshold }\end{array}$ & $\begin{array}{l}\text { Decision: } \\
\text { Acceptable/Un } \\
\text { acceptable }\end{array}$ \\
\hline $\begin{array}{l}\text { Chi-Square } \\
\text { Value: } 2 \text { 2/(df) }\end{array}$ & $<3$ & 2.124 & Acceptable \\
\hline $\begin{array}{l}\text { Comparative Fit } \\
\text { Index (CFI) }\end{array}$ & $>0.900$ & 0.908 & Acceptable \\
\hline $\begin{array}{l}\text { Goodness of Fit } \\
\text { Index (GFI) }\end{array}$ & $>0.900$ & 0.914 & Acceptable \\
\hline $\begin{array}{l}\text { Incremental Fit } \\
\text { Index (IFI) }\end{array}$ & $>0.900$ & 0.909 & Acceptable \\
\hline $\begin{array}{l}\text { Normed Fit Index } \\
\text { (NFI) }\end{array}$ & $>0.900$ & 0.903 & Acceptable \\
\hline $\begin{array}{l}\text { Tucker Lewis } \\
\text { Index (TLI) }\end{array}$ & $>0.900$ & 0.915 & Acceptable \\
\hline $\begin{array}{l}\text { Random Measure } \\
\text { of Standard Error } \\
\text { Approximation } \\
\text { (RMSEA) }\end{array}$ & $<0.080$ & 0.069 & Acceptable \\
\hline
\end{tabular}

Table 9:- Model Fit Summary- Measurement Model

Structural Model Assessment and Hypotheses Testing

The structural model indicates EE, TCB and SI having an effect on the behavioural intention while FC, BI and TCB having a positive effect on EU. Hypotheses assessing model fit were tested after Path analysis was conducted. Path analysis was assessed to establish the magnitude of hypothesised causal connections between the elements. Model fit path analysis outcomes are presented in table 10 as: $\chi 2 / \mathrm{df}=2.811 ; \mathrm{CFI}=0.903 ; \mathrm{IFI}=0.907 ; \mathrm{NFI}=0.933$; TLI $=0.906 ;$ RMSEA $=0.078$. The results indicated all model fit indices being within the recommended levels.

\begin{tabular}{|l|l|l|l|}
\hline Model Fit Indices & \multicolumn{1}{|c|}{$\begin{array}{l}\text { Acceptable } \\
\text { Threshold }\end{array}$} & $\begin{array}{l}\text { Current } \\
\text { Study } \\
\text { Threshold }\end{array}$ & $\begin{array}{l}\text { Decision: } \\
\text { Acceptable/Una } \\
\text { cceptable }\end{array}$ \\
\hline $\begin{array}{l}\text { Chi-Square } \\
\text { Value:X2/(df) }\end{array} \quad<3$ & 2.811 & Acceptable \\
\hline $\begin{array}{l}\text { Comparative Fit } \\
\text { Index (CFI) }\end{array}$ & $>0.900$ & 0.903 & Acceptable \\
\hline $\begin{array}{l}\text { Incremental Fit Index } \\
\text { (IFI) }\end{array}$ & $>0.900$ & 0.907 & Acceptable \\
\hline $\begin{array}{l}\text { Normed Fit Index } \\
\text { (NFI) }\end{array}$ & $>0.900$ & 0.933 & Acceptable \\
\hline $\begin{array}{l}\text { Tucker Lewis Index } \\
\text { (TLI) }\end{array}$ & $>0.900$ & 0.906 & Acceptable \\
\hline $\begin{array}{l}\text { Random Measure of } \\
\text { Standard } \\
\text { Approximation Error } \\
\text { (RMSEA) }\end{array}$ & 0.08 & 0.078 & Acceptable \\
\hline
\end{tabular}

Table 10:- Model Fit Summary- Structural Model

\section{$>$ Structural Model Assessment (Path Analysis)}

Measurement of the hypothesised structural model is done first before examining the causal relationships between latent variables by path analysis (Henseler, Hubona and Ray, 2016). Some latent variables directly or indirectly affect other latent variables in the model resulting in estimated outcomes that explains the relationship of these latent variables as it is emphasised by structural equation modelling (Lefcheck, 2016; Hair et al., 2017). Table 11 presented the estimated results obtained through hypothesis testing. Table 11 indicates if a hypothesis is rejected or accepted and shows the hypotheses, path coefficients and t-statistics. Significant relationship indicators are $\mathrm{t}>1.96$ while a higher path coefficients means stronger relationships between the latent variables (Chinomona, Lin, Wang and Cheng, 2010).

\begin{tabular}{|c|c|c|c|c|c|}
\hline $\begin{array}{l}\text { Hypothesized } \\
\text { Relationship }\end{array}$ & Hypotheses & $\begin{array}{l}\text { Path Co- } \\
\text { efficient }\end{array}$ & $\begin{array}{r}\text { T- } \\
\text { Statistics }\end{array}$ & P-value & OUTCOME \\
\hline $\mathrm{EE} \rightarrow \mathrm{BI}$ & $\mathrm{H} 1$ & 0.015 & 0.569 & 0.000 & $\begin{array}{l}\text { Significant } \\
\text { \& Supported }\end{array}$ \\
\hline $\mathrm{SI} \rightarrow \mathrm{BI}$ & $\mathrm{H} 2$ & 0.144 & 1.789 & 0.074 & $\begin{array}{l}\text { Supported but } \\
\text { insignificant }\end{array}$ \\
\hline $\mathrm{FC} \rightarrow \mathrm{EU}$ & H3 & 0.115 & 1.775 & 0.076 & $\begin{array}{l}\text { Supported but } \\
\text { insignificant }\end{array}$ \\
\hline $\mathrm{BI} \rightarrow \mathrm{EU}$ & $\mathrm{H} 4$ & 0.586 & 11.084 & 0.000 & $\begin{array}{l}\text { Significant } \\
\text { \& Supported }\end{array}$ \\
\hline $\mathrm{TCB} \rightarrow \mathrm{BI}$ & H5 & 0.494 & 4.603 & 0.000 & $\begin{array}{l}\text { Significant } \\
\text { \& Supported }\end{array}$ \\
\hline $\mathrm{TCB} \rightarrow \mathrm{EU}$ & $\mathrm{H} 6$ & 0.192 & 3.623 & 0.000 & $\begin{array}{l}\text { Significant } \\
\text { \& Supported }\end{array}$ \\
\hline
\end{tabular}

Table 11:- Path Analysis Results

Note: BI = Behavioural Intension; EE = Effort Expectancy; $E U=$ e-filing Usage; $F C=$ Facilitating Conditions; $S I=$ Social Influence; TCB = Tax Compliance Behaviour 
Table 11 shows the outcomes of the six hypotheses that were assessed in this study. All hypotheses were positive. After testing $\mathrm{H} 2$ and $\mathrm{H} 3$, insignificant results were obtained as the p-value is over $0.05(0.074,0.076)$.

\section{Structural Equation Modelling (SEM)}

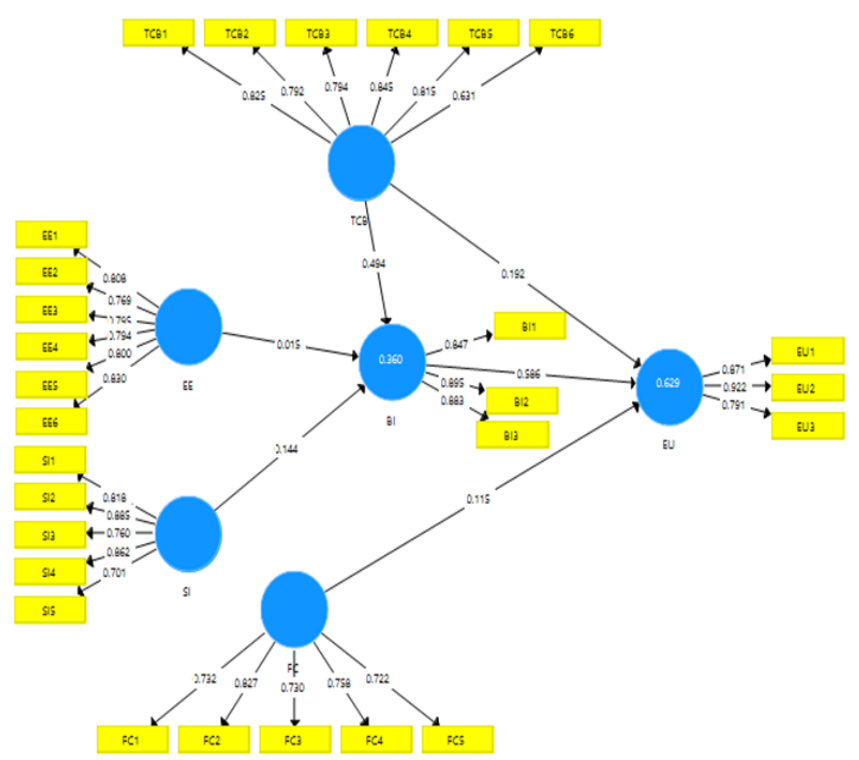

Fig 4:- Flow diagram of Structural Equation Modelling

Path coefficients presented in figure 4 shows the significant levels being measured with the p-values and tstatistics from the six hypotheses tested. Hypotheses significance are recommended at a $95 \%$ or higher level of significance $(\geq 95 \%)$ and p-value at $\leq 0.05$ (Hastie et al., 2009); Hair et al., 2010). The t-statistics with a threshold of greater than 1.96 are acceptable for the relationship purpose. Hypotheses and path coefficients are presented first followed by the t-statistics and p-values showing the significant levels of the relationships and lastly the column showing the decision of accepting or rejecting the proposed hypotheses. A strong relationship between the dependent and the independent variables is indicated by the path coefficients (Hsu, 2008). Four hypotheses were found to have significant level at $\mathrm{p}<0.05$ after testing the probability value which is also known as $\mathrm{p}-$ value.

Four out of the six hypotheses were statistically significant with the exclusion two being $\mathrm{H} 2$ and $\mathrm{H} 3$ which were positive but not significant. Strong relationship was between Behavioural Intension (BI) and Efiling Usage (EU) with $\beta=0.586 ; \mathrm{t}=11.084 ; \mathrm{p}=0.000$ followed by $\mathrm{a}$ relationship amongst Tax Compliance Behaviour (TCB) and Behavioural Intension $(\mathrm{BI})$ with $\beta=0.494 ; \mathrm{t}=4.603$; $\mathrm{p}=0.000$. The third strong relationship is Tax Compliance Behaviour (TCB) and E-filing Usage (EU) having $=\beta$ $0.192 ; \mathrm{t}=3.623 ; \mathrm{p}=0.000$ while in the fourth place is the relationship amongst Social Influence (SI) and Behavioural Intension (BI) with $=\beta 0.144 ; \mathrm{t}=1.789 ; \mathrm{p}=0.074$. Weak relationship is amongst Facilitating Conditions (FC) and Efiling Usage $(E U)$ with $=\beta 0.115 ; \mathrm{t}=1.775 ; \mathrm{p}=0.076$ and the weakest relationship is amongst all hypotheses was amongst Effort Expectancy (EE) and Behavioural Intension (BI) having $=\beta 0.015 ; \mathrm{t}=0.569 ; \mathrm{p}=0.000$.

\section{$>$ Summary of the results for this study}

Results after testing hypotheses as per data analysed indicates path coefficients of $\mathrm{H} 1, \mathrm{H} 2, \mathrm{H} 3, \mathrm{H} 4, \mathrm{H} 5$ and $\mathrm{H} 6$, to be $0.015,0.144,0.115,0.586,0.494$ and 0.192 respectively. Results from this study shows all six latent variables having positive relationships. Behavioural Intension and E-filing Usage had the strongest relationship with path coefficient value of 0.586 while relationship amongst effort expectancy and behavioural intension being the weakest with a path coefficient of 0.015. Testing confirming reliability and validity of the measurement was done. Relationships between the constructs as per hypotheses in this study were assessed using Smart PLS software for SEM.

\section{STUDY RESULTS AND INTERPRETATIONS}

Results and interpretations for this study are presented below. Hypothesis one results shows a positive and significant relationship among Effort Expectancy (EE) and Behavioural Intension (BI) having $=\beta 0.015 ; \mathrm{t}=0.569$; $\mathrm{p}=0.000$. These results are consistent with findings from previous studies that discovered effort expectancy correlating with behavioural intention (Agarwal and Prasad, 1999; Thompson et al., 1991; Venkatesh et al., 2003). These outcomes are indicating effort expectancy having a positive impact behavioural intension, thus taxpayers need an easy to use system. Results from testing hypothesis two confirmed a positive but insignificant relationship amongst social influence and behavioural intension with $=\beta 0.144$; $\mathrm{t}=1.789 ; \mathrm{p}=0.074$. Results from this study confirm claims that taxpayers use online application that are preferred by their peers, friends and family members (Venkatesh and Davis, 2000). Social influence plays an important role for influencing users to accept information system, so revenue application designers must develop strategies to ensure that users get a value for using the electronic filing. Results after testing hypothesis three shows a positive but insignificant relationship amongst facilitating conditions Efiling Usage as per $=\beta 0.115 ; \mathrm{t}=1.775 ; \mathrm{p}=0.076$. These outcomes confirm findings from prior study discovering that focusing on facilitating conditions only does not automatically predict revenue application usage as factors affecting information system usage are plenty ( $\mathrm{Fu}$ et al., 2006). Revenue Application is used at any time of a day and tax authority must ensure the availability of support personnel to attend to system challenges from users. Results for testing hypothesis four shows a strongest positive and a significant relationship amongst behavioural intension and E-filing Usage as per $\beta=0.586$; $\mathrm{t}=11.084$; $\mathrm{p}=0.000$. These outcomes confirm findings from previous studies stating that even if all factors affecting actual use of information system are in place, decision to use technology is not guaranteed. (Agarwal and Prasad, 1999). Hypothesis five testing indicates a strong positive and significant relationship amongst Tax Compliance Behaviour and Behavioural Intension as per $\beta=0.494$; $\mathrm{t}=4.603$; $\mathrm{p}=0.000$. These outcomes are similar to findings by Marziana, 
Norkhazimah and Mohmad (2010), for discovering taxpayers' attitude and perception regarding tax system fairness being a vital factor significantly influencing tax compliance behaviour. Integrity, credibility and trustworthiness of government affect taxpayers' decision to adopt revenue application. Hypothesis six testing indicates a positive and significant relationship amongst Tax Compliance Behaviour and E-filing Usage as per $=\beta 0.192$; $\mathrm{t}=3.623 ; \mathrm{p}=0.000$. This study results concur with claim from previous study showing a tax compliant behaviour and E-filing Usage having a positive relationship (Fischer et al., 1992). These outcomes mean that ethical taxpayers submitting tax returns correctly and on time are likely to use the revenue application platforms than less ethical taxpayers. Tax compliance behaviour changes over time, continuous monitoring by authority is needed.

\section{A MODEL FOR ACCEPTING AND USING REVENUE APPLICATION}

Figure 5 below shows a model for accepting and using the revenue application after the conceptual model was amended according to constructs testing which were done.

\section{A Model for Accepting and Using Revenue Application}

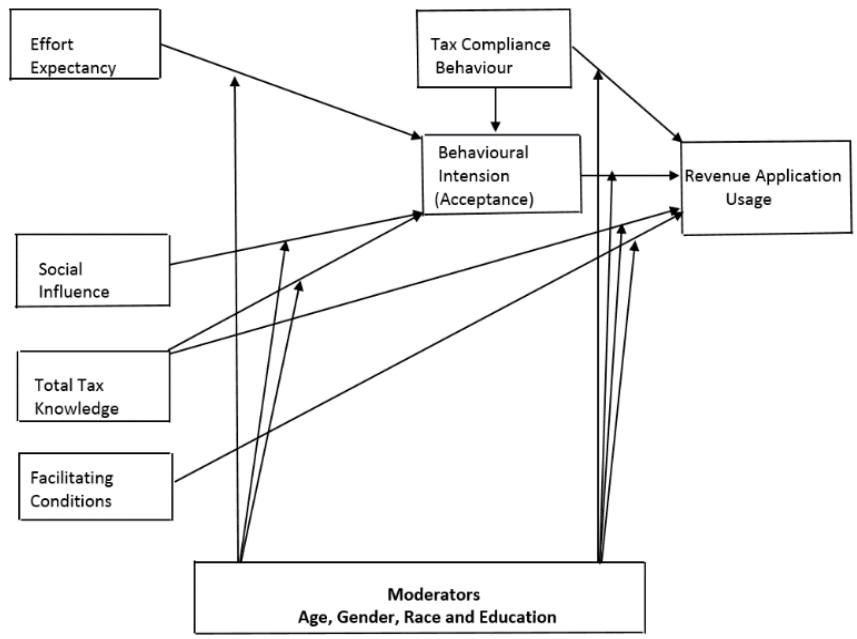

Fig 5:- A Model for Adoption and Usage of Revenue Application

The model for accepting and using revenue application being developed in this paper has the following constructs as tested results: Behavioural Intension, Revenue Application Usage, Effort expectancy, facilitating conditions, social influence, tax compliance behaviour and total tax knowledge. Most of these elements were validated in this study except total tax knowledge that is an additional element for this model. It can be conclusion that these elements are the determinants for the accepting and using the revenue application. Additional construct being total knowledge was used when reviewing the conceptual model, higher education is linked to a higher possibility of tax compliance in previous literature. Taxpayers with tertiary education comply tax obligations than their counterparts without tertiary education.

\section{CONCLUSION}

Model fit summary presented in table 10 shows all model fit indices being, chi-square value, comparative fit index, incremental fit index, normed fit index, tucker Lewis index and random measure of standard error approximation, having values greater than the recommended levels. Path analysis outcomes show four hypotheses being supported and significant excluding $\mathrm{H} 2$ and $\mathrm{H} 3$ that are positive but insignificant. Reliability and validity tests in confirmatory factor analysis (CFA) respectively indicates outcomes verifying reliability and validity of measurement. This study confirmed factors for accepting and using revenue application to be effort expectancy, facilitating conditions, social influence, behavioural intension and tax compliance behaviour. Tax authorities can consider to practically apply the model developed in this study to achieve an optimal usage of the revenue application. Research problem was that despite South Africa having excellent revenue application, queues at its tax branch offices are still observable being for taxpayers submitting manual tax returns. This study shared more inside information for exploring reasons why other taxpayers accept and use the revenue application while others do not. This study has come up with a solution to the research problem by developing a model for accepting and using the revenue application. Reasons relating to why taxpayers are using the revenue application while others are not using it are now known as per results from this study. Tax authority need to focus on these factors to influence taxpayers to optimally use the revenue application.

\section{REFERENCES}

[1]. Agarwal, R. and Prasad, I (1999). "Are individual differences germane to the acceptance of new information technologies?" Decision Sciences, Vol. 30, No. 2, pp. $361-391$

[2]. Ajzen, I. (1991). The theory of planned behaviour. Organisational behaviour and human decision processes, 50(1), pp. 179-211.

[3]. Alm, J., Cherry, T., Jones, M. and McKee, M (2012). Social Programs as positive inducements for tax participation. Journal of Economic Behaviour \& Organization 84(1): 85-96.

[4]. Azmi, A. A. C., and Kamarulzaman, Y. (2010). Adoption of Tax e-filing: A Conceptual Paper. African Journal of Business Management Vol., 4(5), 599-603.

[5]. Barjoyai, B. (1992). Tax illiteracy in Malaysia: Problems and solutions. ACCAMADIA, Journal of Faculty of Accountancy, Faculty of Accountancy, UiTM Shah Alam 11(2): 6-35.

[6]. Barodiva, P and Bhargava, A (2015). E-Filing Awareness of Income Tax returns - International Journal of Multidisciplinary Research and Development. Volume: 2, Issue: 6, 119-122 June 2015. 
[7]. Baumgartner, H., and Homburg, C. (1996). Applications of structural equation modeling in marketing and consumer research: A review. International Journal of Research in Marketing, 13(2), 139-161.

[8]. Bentler, P.M. and Bonnet, D.C. (1980). Significance Tests and Goodness of Fit in the Analysis of Covariance Structures, Psychological Bulletin, 88 (3), 588-606.

[9]. Beynon-Davies, P. (2005). Constructing electronic government: the case of the UK inland revenue. International Journal of Information Management 25(1): 3-20

[10]. Bickman, L. and Rog, G.J (2008). The SAGE handbook of applied social research methods, Sage publications.

[11]. Bollen, K. A. (1989). Structural equations with latent variables. New York, NY: Wiley

[12]. Brewer, C.S., Chao, Y.Y., Colder, C.R., Kovner, C.T. and Chacko, T.P. (2015). A structural equation model of turnover for a longitudinal survey among early career registered nurses. International journal of nursing studies, 52(11), pp.1735-1745.

[13]. Byrne, B.M. (2016). Structural equation modelling with AMOS: Basic concepts, applications, and programming. Routledge.

[14]. Canivez, G.L. (2016). Bifactor modelling in construct validation of multifactored tests: Implications for understanding multidimensional constructs and test interpretation. Gottingen, Germany: Hogrefe Publishers.

[15]. Carter, L and Belanger, F (2005). "The Utilization of E-Government Services: Citizen Trust, Innovation and Acceptance Factors", Information Systems Journal, vol. 15, n. 1: 5-25. http://dx.doi.org/10.1111/j.13652575.2005.00183.x

[16]. Carter, L., Schaupp, L.C., Hobbs, J. and Campbell, R. (2011a). The role of security and trust in the adoption of online tax filing. Transforming Government: People, Process, Policy, 5(4), pp. 303-318.

[17]. Carter, L., Schaupp, L.C. and McBride, M.E. (2011b). The U.S. e-file initiative: an investigation of the antecedents to adoption from the individual taxpayers' perspective. E - Service Journal, 7(3), pp. 219.

[18]. Chau, P.Y., 1997. Re-examining a model for evaluating information centre success using a structural equation modelling approach. Decision Sciences, 28(2), pp.309-334.

[19]. Chau, Y. K and Hu, J. H (2001). Information technology acceptance by individual professionals: a model comparison approach. Decision Sciences, 32.

[20]. Chinomona, R. (2011). Non-mediated channel powers and relationship quality: $A$ case of SMEs in Zimbabwe channels of distribution. National Central University, Taiwan, 1-175.

[21]. Chinomona, R., Lin, J.Y.C., Wang, M.C.H. and Cheng, J.M.S. (2010). Soft power and desirable relationship outcomes: the case of Zimbabwean distribution channels. Journal of African Business, 11(2), pp.182-200.
[22]. Crego, C., Samuel, D. B., and Widiger, T. A. (2015). The FFOCI and other measures and models of OCPD.

[23]. Crego, C., Gore, W.L., Rojas, S.L. and Widiger, T.A. (2015). The discriminant and convergent validity of the Personality Inventory for DSM-5. Personality Disorders: Theory, Research, and Treatment, 6(4), p.321.

[24]. Crotty, M (1998). The Foundation of Social Research: Meaning and Perspectives in the Research Process. London: Sage.

[25]. Cronbach, L. J (1951). "Coefficient alpha and the Internal structure of test", Psychometrical, Vol. 16, No. 3, pp. $297-334$.

[26]. Crotty, M (1998). The Foundation of Social Research: Meaning and Perspectives in the Research Process. London: Sage.

[27]. Davis, F.D (1989). Perceived Usefulness, Perceived Ease-of-Use, and User Acceptance of Information Technology, MIS Quarterly, 13(3), pp. 319-339.

[28]. De Castro, J. A. C., Cordero, M. J. D., De Chavez, J. R., Gabia, M. F. P., Mortel, S. A. A., Yortas, J. C., Manongsong, J. L. and Pateña, A. D. (2015). Awareness on BIR e-Filing and Payment System: Basis for Efficient Revenue Transactions. Asia Pacific Journal of Academic Research in Business Administration, 1(1), 32-40.

[29]. DeLone, W. H. and McLean, E. R. (2003). The DeLone and McLean model of information systems success: A ten-year update. Journal of Management Information Systems, 19,4,9-30.

[30]. Devine, R.T. and Hughes, C. (2016). Measuring theory of mind across middle childhood: reliability and validity of the silent films and strange stories tasks. Journal of Experimental Child Psychology, 149, pp.23-40.

[31]. Diedenhofen, B. and Musch, J. (2016). A Web Interface and $\mathrm{R}$ Package for the Statistical Comparison of Cronbach's Alpha Coefficients. International Journal of Internet Science, 11(1).

[32]. Dillon, A and Morris, M (1996). User acceptance of information technology: theories and models. In: M. Williams (ed.), Annual Review of Information Science and Technology, Vol. 31, (Medford, NJ: Information Today).

[33]. Easterby-Smith, M., Thorpe, R and Lowe, A (2006). Management Research: An introduction, 2nd Edition, Sage Publications

[34]. Featherman, M. S. and P. A. Pavlou (2003). "Predicting e-services adoption: a perceived risk facets perspective," International Journal of HumanComputer Studies (594), 2003, pp. 451-474.

[35]. Fischer CM, Wartick M, Mark M (1992). Detection Probability and Taxpayer Compliance: A Review of the Literature. J. Acc. Lit. 11: 1-46.

[36]. Fishbein M, Ajzen I (1975). Belief, Attitude, Intention and Behaviour: An introduction to theory and research, Reading, MA: Addison Wesley.

[37]. Fu, J. R., Farn, C. K and Chao, W. P (2006). Acceptance of electronic tax filing: A study of taxpayer intentions. Information \& Management 43, $109-126$ 
[38]. Gilbert, D., Balestrini, P and Littleboy, D. (2004). Barriers and Benefits in the Adoption of eGovernment. The International Journal of Public Sector Management, 17(4), 286-301.

[39]. Goodhue, D.L and Thompson, R. L (1995) Tasktechnology fit and individual performance MIS Quarterly; Jun 1995; 19, 2; ABI/INFORM Global pg. 213-236.

[40]. Gupta, B., Dasgupta, S., and Gupta, A. (2008). Adoption of ICT in a government organization in a developing country: An empirical study. Journal of Strategic Information Systems, 17(2), 140-154.

[41]. Hair Jr, J.F., Hult, G.T.M., Ringle, C. and Sarstedt, M. (2016). A primer on partial least squares structural equation modelling (PLS-SEM). Sage Publications.

[42]. Hair, J.F., Hult, G.T.M., Ringle, C.M., Sarstedt, M. and Thiele, K.O. (2017). Mirror, mirror on the wall: A comparative evaluation of composite-based structural equation modelling methods. Journal of the Academy of Marketing Science, 45(5), pp.616-632.

[43]. Hastie, T., Tibshirani, R., and Friedman, J. (2009). The elements of statistical learning: Data mining, inference, and prediction (2nd ed.). New York, NY: Springer.

[44]. Hsu SH. (2008). Developing an index for online customer satisfaction: adaptation of American Customer Satisfaction Index. Expert Syst Appl. 2008;34(4):3033-3042. doi: 10.1016/j.eswa.2007.06.036.

[45]. Hair, J. F., Black, W. C., Babin, B. J., and Anderson, R. E. (2010). Multivariate data analysis (7th ed.). Englewood Cliffs: Prentice Hall

[46]. Hasseldine, J., Holland, K. and Rijt, P.V. (2009). The Management of Tax Knowledge. The Association of Chartered Certified Accountants, ACCA, London.

[47]. Henseler, J., Hubona, G. and Ray, P.A. (2016). Using PLS path modelling in new technology research: updated guidelines. Industrial management \& data systems, 116(1), pp.2-20.

[48]. Henseler, J., Ringle, C.M. and Sarstedt, M. (2015). A new criterion for assessing discriminant validity in variance-based structural equation modelling. Journal of the academy of marketing science, 43(1), pp.115135.

[49]. Hooper, D., Coughlan, J., and Mullen, M. R. (2008). Structural Equation Modelling: Guidelines for Determining Model Fit. Electronic Journal of Business Research Methods, 6(1), 53-60.

[50]. Hox, J.J., Moerbeek, M. and Van de Schoot, R. (2017). Multilevel analysis: Techniques and applications. Routledge.

[51]. Kim, D. J., D. L. Ferrin and RAO, R (2008). "A trustbased consumer decision-making model in electronic commerce: The role of trust, perceived risk, and their antecedents," Decision Support Systems (442), 2008, pp. 544-564.

[52]. Kirchler, E., Niemirowski, A., and Wearing, A. (2006). Shared subjective views, intent to cooperate and tax compliance: Similarities between Australian taxpayers and tax officers. Journal of Economic Psychology, 27, 502-517.
[53]. Kumar, M., and Anees, M (2014). E-filing: Creating new revolution in taxation of India. Global Journal of Finance and Management, 6(4), 379-384. Retrieved from www.ripublication.com

[54]. Lai, M and Choong, K. (2010). Motivators, Barriers and Concerns in Adoption of Electronic Filing System: Survey Evidence from Malaysian Professional Accountants. American Journal of Applied Sciences, 3(4), 10-15.

[55]. Lee, J., Kim, H.J and Ahn, M. J (2011). "The Willingness of E-Government Service Adoption by Business Users: The Role of Offline Service Quality and Trust in Technology", Government Information Quarterly, vol. 28: 222-230.

[56]. Lefcheck, J.S. (2016). Piecewise SEM: Piecewise structural equation modelling in $r$ for ecology, evolution, and systematics. Methods in Ecology and Evolution, 7(5), pp.573-579.

[57]. Leitner, C. (2003). E-Government in Europe: The state of affairs, Proceedings of the e-Government 2003 Conference, Como, Italy.

[58]. Marziana Hj. Mohamad, Norkhazimah Ahmad, Mohmad Sakarnor Deris (2010). Perceptions of Taxpayers With Level of Compliance: A Comparison in the East Coast Region, Malaysia: Journal of Global Business and Economics, vol.1, issue 1, pages 241257

[59]. McDonald, R.,P and Ho, M. R (2002). Principles and Practice in Reporting Structural Equation Analyses. University of Illinois at Urbana-Champaign Psychological Methods by the American Psychological Association, Inc.

Vol. 7, No. 1, 64-82

[60]. Miles, M.B., Huberman, A.M., Huberman, M.A., and Huberman, M. (1994). Qualitative data analysis: An expanded sourcebook. Sage.

[61]. Moorthy, M. K., Samsuri, A. S. B., Hussin, S. B. M., Othman, M. S. B., and Chelliah, M. K. (2014). EFiling Behaviour among Academics in Perak State in Malaysia. Technology and Investment, 5(2), 79-94.

[62]. Mustapha, B. (2015). Evaluation of e-Tax Quality Implementation Criteria: the Case of Self-Employed Taxpayers in Nigeria. International Journal of Computer and Electronics Research, 4(2), 39-45.

[63]. Popper, Karl. (1968). The Logic of Scientific Discovery . New York : Harper.

[64]. Preacher, K.J., Zhang, Z. and Zyphur, M.J. (2016). Multilevel structural equation models for assessing moderation within and across levels of analysis. Psychological methods, 21(2), p.189.

[65]. Rehman, M., Esichaikul, V., and Kamal, M. (2012). Factors Influencing e-Government Adoption in Pakistan. Transforming Government: People, Process and Policy, 6(3), 258-282.

[66]. Santhanamery, T., and Ramayah, T. (2015). Understanding the Effect of Demographic and Personality Traits on the e-filing Continuance Usage Intention in Malaysia. Global Business Review, 16(1), $1-20$. 
[67]. Schermelleh-Engel, K., Klein, A. and Moosbrugger, H. (2017). Estimating nonlinear effects using a latent moderated structural equations approach. In Interaction and nonlinear effects in structural equation modelling (pp. 203-238). Routledge.

[68]. Schlemenson, A (1992). Organisational structure and human resources in tax administration. In R. M. Bird \& M. C. d Jantscher (Eds.), Improving tax administration in developing countries (pp. 343-364). Washington, DC: International Monetary Fund.

[69]. Silvani, C.A (1992). Improving Tax Compliance. In Richard M. Bird and Milka Casanegra de Jantscher (Eds), Improving Tax Administration In Developing Countries. Washington D.C. International Monetary Fund, Publication Service.

[70]. Thompson, R., Higgins, C and Howell, J (1991). Personal computing: toward a conceptual model of utilization. MIS Quarterly, 15(1), 124-143.

[71]. United Nations (2005). Global e-Government readiness report 2005: From e-government to $e$ inclusion.

[72]. Van der Berg, S and Bhorat, H (1999). The present as a legacy of the past: The labour market, inequality and poverty in South Africa. (DPRU Working Paper 01/29) Development Policy Research Unit, University of Cape Town, South Africa.

[73]. Venkatesh, V and Davis, F.D (2000). A Theoretical Extension of the Technology Acceptance Model for longitudinal field studies. International Journal of Management Sciences, 46(2), pp 186-204.

[74]. Venkatesh, V., Morris, M., Davis, G. and Davis, F. (2003). "User acceptance of information technology: toward a unified view", MIS Quarterly, Vol. 27 No. 3, pp. 425-478.

[75]. Wang, Y.S. (2002). The adoption of electronic tax filing systems: an empirical study. Government Information Quarterly, 20(1), pp. 333-352.

[76]. Wasao, D. (2014). The effect of online tax system on tax compliance among small taxpayers in east of Nairobi tax district. MSc. in Finance thesis, University of Nairobi, Kenya.

[77]. Willoughby, M.T., Kuhn, L.J., Blair, C.B., Samek, A. and List, J.A. (2017). The test-retest reliability of the latent construct of executive function depends on whether tasks are represented as formative or reflective indicators. Child Neuropsychology, 23(7), pp.822-837.

[78]. Wilcox, R. R. (1996). Statistics for the social sciences. Academic Press.

[79]. Wirtz, B. W., and Piehler, R. (2016). E-Government Applications and public personnel Acceptance: An Empirical Analysis of the Public Servant Perspective. International Journal of Public Administration, 39(3), 238-247.

[80]. Zelkowitz, R.L. and Cole, D.A. (2016). Measures of emotion reactivity and emotion regulation: Convergent and discriminant validity. Personality and Individual Differences, 102, pp.123-132. 